\title{
Deoxyribonucleic Acid Base Composition of Ovine Actinobacilli
}

\author{
By R. C. GUMBRELL* AND J. M. B. SMITH \\ Department of Microbiology, University of Otago Medical School, Dunedin, New Zealand
}

(Received 18 April 1974)

In New Zealand and elsewhere, three groups of organisms predominate in the aetiology of ovine epididymitis. These are Brucella ovis, actinobacilli, and a group referred to simply as Gram-negative pleomorphic bacilli (Ekdahl, Money \& Martin, I968; Watt, 1972). While some of the actinobacilli closely resemble authentic species of the genus, e.g. Actinobacillus lignieresii, many are simply referred to as Actinobacillus-like or 'Actinobacillus seminis'. This binomial was first used by Baynes \& Simmons (I960) for a series of apparently rather biochemically inert Gram-negative bacilli, recoverable from ram testicular lesions, which for maximal growth required lowered oxygen tensions and serum enrichment. The organisms appeared to be members of the family Brucellaceae Breed et al. and were considered, perhaps wrongly, to be most closely related to the genus Actinobacillus. Despite the fact that the original description was not based on a single designated type strain, $A$. seminis has been accepted by Hatt \& Zvirbulis (1967) as a validly published and legitimate binomial. Since then, reports of ovine epididymitis associated with the same or similar organisms have been made in a number of countries (Watt, 1972).

Over recent years, techniques have become available for comparing bacterial genomes including the estimation of the deoxyribonucleic acid base ratios (Marmur \& Doty, 1962). Organisms with closely related base compositions are believed to be phylogenetically related if they possess similar morphological, physiological, biochemical and other characteristics (Jones \& Sneath, I970). For this reason, the guanine-cytosine base ratio of a group of Actinobacillus-like organisms isolated from ovine genital lesions has been compared with known type strains of $A$. lignieresii and $A$. equuli, in an attempt to demonstrate some sort of relationship between them.

\section{METHODS}

Organisms. A total of 13 actinobacilli or Actinobacillus-like strains, details of which are given in Table $\mathrm{I}$, were maintained on blood agar plates at $37^{\circ} \mathrm{C}$ in a candle jar and routinely subcultured every 2 or 3 days.

Each organism, except strain $\mathrm{M}$, was grown on blood agar (BBL trypticase soy agar with I0\% human blood) in autoclavable polypropylene instrument trays $(20 \times 15 \times 5 \mathrm{~cm})$ with overlapping lids, containing approximately $200 \mathrm{ml}$ of media. Trays were inoculated with $3 \mathrm{ml}$ of a saline suspension $\left(10^{8}\right.$ organisms $/ \mathrm{ml}$ ) of the appropriate bacterial strain spread over the surface of the medium by gently shaking and rocking the covered trays, and incubated at $37^{\circ} \mathrm{C}$ for $20 \mathrm{~h}$ in a cabinet with a front hinged door securely fastened and sealed with a foam rubber strip. Before the door was closed, a lighted candle was placed in the cabinet.

Cells were harvested using sterile saline $(0.9 \% \mathrm{NaCl})$ and a sterilized glass microscope slide as a scraper. After washing twice in saline, portions (approx. I g) were resuspended in

* Present address: Animal Health Laboratory, Ministry of Agriculture and Fisheries, Box 24, Lincoln, New Zealand. 
Table I. Details of organisms studied and their DNA base compositions

\begin{tabular}{cl}
$\begin{array}{c}\text { Strain } \\
\text { no. }\end{array}$ & \multicolumn{1}{c}{ Source } \\
A & Ovine epididymitis, New Zealand \\
B & Ovine epididymitis, New Zealand \\
C & Ovine epididymitis, New Zealand \\
F & Bovine tongue nodule, New Zealand \\
G & Ovine epididymitis, New Zealand \\
H & Vertebral abcess of a lamb, New \\
& Zealand \\
I & Ovine epididymitis, New Zealand \\
J $\dagger$ & Ovine epididymitis, Australia \\
K & Bovine semen, New Zealand \\
L & Kidney, ureter, bladder of a sheep, \\
& New Zealand \\
M $\ddagger$ & NCTC8529, Colindale \\
N $\dagger$ & NCTC4976, Colindale \\
O & Ovine scrotal abscess, New Zealand
\end{tabular}

Tentative

identification

Actinobacillus species

Actinobacillus species

Actinobacillus species

A. lignieresii

A. seminis

A. lignieresii

A. seminis

A. seminis

A. seminis

Actinobacillus species

A. equuli
A. lignieresii
A. seminis
DNA base composition $(\mathrm{mol} \% \mathrm{G}+\mathrm{C})$

$42 \cdot 2 \pm I \cdot 7^{*}$

$45 \cdot 9 \pm 0 \cdot 7$

$47 \cdot 9 \pm \mathrm{I} \cdot 2$

$47 \cdot I \pm 0 \cdot 0$

$45 \cdot 0 \pm \mathrm{I} \cdot 9$

$41 \cdot 9 \pm 0 \cdot 6$

$39 \cdot 0 \pm 0 \cdot 7$

$48 \cdot 8 \pm 0 \cdot 7$

$38 \cdot 7 \pm 0 \cdot 4$

$42 \cdot 9 \pm 0 \cdot 4$

$4 \mathrm{I} \cdot 3 \pm \mathrm{I} \cdot \mathrm{O}$

$43 \cdot 6 \pm 0 \cdot 7$

$37 \cdot 8 \pm 0 \cdot 8$

* Standard deviation, corrected for small groups.

$\dagger$ Original isolate of Baynes \& Simmons (1960).

$\$$ Proposed working types (Sneath \& Skerman, 1966).

$25 \mathrm{ml}$ saline-EDTA (0.I5 M-sodium chloride, 0.1 M-ethylenediaminetetra acetate) $\mathrm{pH} 9.0$ and stored at $4{ }^{\circ} \mathrm{C}$ until required.

As strain $\mathrm{M}(A$. equuli) adhered strongly to the agar and was difficult to harvest by the above procedure it was grown in liquid medium, which consisted of nutrient broth (Difco) dispensed in $330 \mathrm{ml}$ portions in $600 \mathrm{ml}$ bottles, autoclaved, cooled, inoculated with a loopful of organisms, and incubated at $37^{\circ} \mathrm{C}$ on a Griffin Orbital Shaker at 88 oscillations/min. After $20 \mathrm{~h}$ the bacteria from each bottle were harvested by centrifuging, pooled, washed twice in saline, and portions (approx. I g) resuspended and stored in $25 \mathrm{ml}$ of salineEDTA pH 9.0 as described above. Blood agar cultures taken from each bottle revealed no contamination.

Extraction of DNA and determination of DNA base composition. The technique of DNA extraction was that of Marmur (196I) with variations as described by Bowie et al. (1972).

The DNA base compositions were determined by the 'melting point' method of Marmur \& Doty (1962). For producing the DNA melting curves the system of Bowie et al. (1972) was used and the DNA dissolved in phosphate-EDTA buffer. At least three melting-point determinations were made on each DNA sample.

\section{RESULTS AND DISCUSSION}

Examination of the results (Table I) reveals a range of $\%$ GCs from $37 \cdot 8$ to $48 \cdot 8$. The values for the two type cultures were consistent with the range (40 to 43) previously reported for the genus Actinobacillus (Jones \& Sneath, 1970; Bailie, Coles \& Weide, 1973). As a difference of $\%$ GC of 5 usually implies at least a species difference (Jones \& Sneath, I 970), it is obvious that the nine isolates considered as probable or confirmed ' $A$. seminis' are not of one species, and possibly not of one genus.

An attempt to clarify some of the taxonomic abnormalities within the family Brucellaceae Breed et al. has recently been made (Johnson \& Sneath, 1973; Sneath \& Johnson, 1973). Using a series of 134 characters, a close phenetic relationship was demonstrated between the 
three genera Actinobacillus, Pasteurella and Haemophilus, suggesting that they might best be separated from other genera of the family, such as Brucella, from which they were phenetically very different. Among the properties listed for actinobacilli were: the anaerobic fermentation of glucose with the production of acid but no gas; the production of acid aerobically from glucose, mannitol and xylose; the formation of the enzymes phosphatase, catalase and urease; the reduction of nitrates to nitrites; and the production of $\mathrm{H}_{2} \mathrm{~S}$. They did not require $\mathrm{X}$ or $\mathrm{V}$ factors or a raised $\mathrm{CO}_{2}$ tension for growth. Although primary isolation is best accomplished on slightly alkaline blood- or serum-enriched media in an atmosphere of $10 \% \mathrm{CO}_{2}$, actinobacilli should, on subculture, grow on nutrient agar and produce small colonies on MacConkey plates. Of the II probable actinobacilli included in the present investigations, only one (isolate $\mathrm{H}$ ) came close to fulfilling all these biochemical requirements; the $\% \mathrm{GC}$ value of this isolate also fell within the required range. Of the remaining ten isolates, three (including $\mathrm{J}$ ) did not produce acid from glucose and mannitol, three (including $\mathrm{J}$ ) did not reduce nitrates, and none grew on MacConkey or produced $\mathrm{H}_{2} \mathrm{~S}$. Most other tests were negative. These results, as well as those of several other workers (see Wetmore, Thiel, Herman \& Harr, I963; Bailie et al. 1973; Johnson \& Sneath, 1973) warrant a reappraisal of the taxonomic position of supposedly Actinobacillus-like organisms recoverable from animals. Indeed, it seems that many of the taxonomic problems now becoming apparent stem directly from the failure of earlier investigators to compare their 'new' species with designated type and reference strains.

We wish to thank Miss J. A. Brooks, Miss H. M. McInnes, Dr R. B. Marshall, Mr D. Martinovich and Mr G. C. Simmons for supplying some of the isolates included in this investigation. The advice of Mr M. C. Connell on DNA extraction techniques is also gratefully acknowledged.

\section{REFERENCES}

BaIlie, W. E., Coles, E. H. \& Weide, K. D. (1973). Deoxyribonucleic acid characterization of a microorganism isolated from infectious thromboembolic meningoencephalomyelitis of cattle. International Journal of Systematic Bacteriology 23, $231-237$.

Baynes, I. D. \& Simmons, G. C. (1960). Ovine epididymitis caused by Actinobacillus seminis, n.sp. Australian Veterinary Journal 36, 454-459.

Bowie, I. S., Grigor, M. R., Dunckley, G. G., Loutit, M. W. \& Loutit, J. S. (1972). The DNA base composition and fatty acid constitution of some Gram-positive pleomorphic soil bacteria. Soil Biology and Biochemistry 4, 397-4I2.

Ekdahl, M. O., Money, D. F. L. \& Martin, C. A. (I968). Some aspects of epididymitis of rams in New Zealand. New Zealand Veterinary Journal 16, 81-82.

HATT, H. D. \& Zvirbulis, E. (1967). Status of names of bacterial taxa not evaluated in Index Bergeyana (I966). I. Names published circa 1950-1967 exclusive of the genus Salmonella. International Journal of Systematic Bacteriology 17, 17 I-225.

Johnson, R. \& SNeATH, P. H. A. (1973). Taxonomy of Bordetella and related organisms of the families Achromobacteraceae, Brucellaceae and Neisseriaceae. International Journal of Systematic Bacteriology 23, 38I-404.

Jones, D. A. \& Sneath, P. H. A. (1970). Genetic transfer and bacterial taxonomy. Bacteriology Reviews 34 , 40-8I.

MARMUR, J. (196I). A procedure for the isolation of deoxyribonucleic acid from micro-organisms. Journal of Molecular Biology 3, 208-2 I8.

MARMur, J. \& DotY, P. (1962). Determination of the base composition of deoxyribonucleic acid from its thermal denaturation temperature. Journal of Molecular Biology 5, 109-1 I8.

SNeAth, P. H. A. \& Johnson, R. (1973). Numerical taxonomy of Haemophilus and related bacteria. International Journal of Systematic Bacteriology 23, 405-418. 
SNEATH, P. H. A. \& SKerman, V. B. D. (1966). A list of type and reference strains of bacteria. International Journal of Systematic Bacteriology 16, I-133.

WATT, D. A. (1972). Testicular abnormalities and spermatogenesis of the ovine and other species. Veterinary Bulletin 42, 181-190.

Wetmore, P. W., Thiel, J. F., Herman, W. F. \& HarR, J. R. (1963). Comparison of selected Actinobacillus species with a hemolytic variety of Actinobacillus from irradiated swine. Journal of Infectious Diseases I13, 186-194. 